\title{
Women in the Political Process and Human Rights: The Nigerian Experience ${ }^{1}$
}

\author{
By Nimah Modupe Abdulraheem*
}

The low level of women participation in the Nigeria political process has hindered their contribution to the development of Nigeria. Though there is no disputing the fact that involvement of women in politics in the recent past has improved tremendously. This is noticeable in the areas of voting and support for their fellow women. However, the actual increase has not been fully translated into the expected women representation in all tiers of government. This is because the number of women holding public offices remains relatively low when compared with their male counterparts. Although the political rights of women enshrined in international, national and regional conventions in various African states are noteworthy, yet they are observed in theory than in practice. Therefore, this paper examines the political participation of women in Nigeria with a view to determining the level of their representation in governance and decision-making of the country. It also examines the factors responsible for the low level of participation of women in politics and governance in Nigeria with a view to providing possible solutions. The work begins by presenting an historical survey of women participation in politics from Pre-colonial to Post-colonial periods. However, emphasis is cantered on Post-colonial period. The work analyses the various legal provisions protecting the political rights of women, many of which Nigeria signs and ratified. It further examines the challenges inhibiting the involvement of women in politics in Nigeria and thereafter concludes by offering suggestions and recommendations for the advancement of political participation of women in Nigeria as their inherent rights. ${ }^{l}$

Keywords: Women, Politics, Participation, Representation, Nigeria.

\section{Introduction}

The position of women in Nigerian politics reflects their subordinate status. This is however not peculiar to Nigeria but Africa and the world at large. All over the world, women have continuously accused their male counterparts of chauvinism. In Nigeria, the general belief is that the leadership history of Nigeria has been male dominated and women have not had a fair share of the cake of leadership role in Nigeria. They have therefore been seeking for equal power sharing in governance like their counterparts elsewhere in the world. On a cursory look of women participation in politics, it can be said that the involvement of women in politics in the recent past has imp proved

\footnotetext{
${ }^{*} \mathrm{PhD}$ Reader, Department of Jurisprudence and International Law, Faculty of Law, University of Ilorin, Ilorin, Nigeria.

${ }^{1}$ This is a revised edition of the paper presented at 13th Annual International Conference of Academy African Business and Development (IAABD), held at Mazagan Hotel and Resorts, El Jadidah, Morocco. 15th -19th May, 2012.
} 
tremendously. However, this is only noticeable in the areas of voting and support for their women folk and their chosen political parties. This has not, however, been fully translated into women representation in all tiers of government. This is because the number of women holding public offices is relatively low when compared with that of their male counterparts. It is noted that the political right of women is unequivocally enshrined in many international ${ }^{2}$, regional $^{3}$ and national ${ }^{4}$ legislations. Nigeria has even gone to the extent of domesticating some of the provisions of the laws into her local law. This has not brought any considerable change in the level of participation of women in politics and of course the decision making of the nation.

Naturally, women are moving into such highly visible positions in other spheres of life as there seems to be a tidal change in the political terrain as more women are now visible in public offices. Yet, they still remain distinctly in the minority in politics. ${ }^{5}$ Against this backdrop, this paper examines the changing participation of women in politics and decision-making in Nigeria, with a view to determining the actual level of their representation in the new political trend and governance in Nigeria. It also critically examines the challenges responsible for the low level of women participation in politics and governance with a view to proffer suggestions and possible solutions that will enhance the representation of women in politics and decision making of Nigeria.

Therefore, this work is divided into four parts. Part one x-rays the participation of women in Nigerian's politics before, during and after colonisation. Part two critiques some notable human rights instruments which enhance and promote women participation in politics. This is done with a view to supporting the contention that women have equal legal rights to governance and decision making processes. The third part, on the other hand, critically examines factors militating against women's active participation in politics and holding of political offices in particular. The last part, part four, brings out some suggestions and recommendations which, if adopted, will enhance active participation of women in politics as well as allowing them to occupy key political offices in Nigeria.

\section{Women Participation in Nigerian Political Process}

It is not an understatement to allude to the fact that political process in Nigeria does not start after independence. This is because the historical antecedents of some notable men and women in the eighteenth and nineteenth centuries Nigerian politics underscores the fact that politics is as old as people of the nation later known as Nigeria. Against this background, this segment is

\footnotetext{
${ }^{2}$ See for example, Universal Declaration of Human Rights (1948), International Covenant on Civil and Political Rights (1966), International Covenant on Economic and Social Rights (1966) and Convention on the Elimination of All Forms of Discrimination against Women (CEDAW) 1979 discussed in more details, infra.

${ }^{3}$ See for example, African Charter on Human and Peoples' Rights (1981)

${ }^{4}$ See the Constitution of the Federal Republic of Nigeria, 1999, particularly Chapter 2 and 4.

${ }^{5}$ Klenke (2011) at 47.
} 
divided into women participation in political process of Nigeria before Precolonial, Colonial and Post- colonial periods.

\section{Women Participation in the Pre-colonial Nigerian Political Process}

The legal status of women in Pre-colonial Nigeria reflected their subordinate nature to their male counterparts. Some customary law in existence imposed limitations on women, especially in the area of politics which made them subordinate to their male counterparts. ${ }^{6}$ For instance, Ibobio women could not be the head of household, lineage and sub-lineage like her male counterparts. As such could not sit in the Council with the male chiefs at these levels. Similarly the powers of Omu and her Council were not as extensive as that of her male counterparts, the Obi. Also, Iyalode was the only woman chief in a council of at least ten male chiefs. In the same vein, the wives of the rulers were killed and buried along with the rulers when they died. ${ }^{7}$ Despite these limitations, they were able to make active impact in the economic and sociopolitical sectors of their various communities. ${ }^{8}$ It is on record that this period witnessed a lot of women playing key roles in places of rulers. ${ }^{9}$ Notwithstanding the prominent roles played by these women, the imposition of certain limitations is a testimony to the fact that the powers exercised by them in political activities of some communities are far less than their male counterparts.

Apart from the imposition of certain limitations, it was also not common to see women as absolute rulers. Many African leaders had influential women around them to represent the interest of women folk. They rule in conjunction with the male rulers and therefore played active advisory roles in conjunction with their male counterparts. For instance, in Ghana (especially in Asante) and in the Southern part of Nigeria, women leaders were co-opted to help the king in the administration of the $\operatorname{state}^{10}$. In the old Benin kingdom, it was the practice of the ruling monarch to confer on his mother the title of "Iyoba" (Queen's mother) three years after his accession to the throne. Thereafter, "Iyoba" will be sent to Uselu, a part of the Kingdom, to reign as 'Iyoba Uselu' and become one of the King's important advisers until she dies. ${ }^{11}$ Similarly, in some parts of Igbo land, there was the institution of Omu, which is a Council of women similar to that of the Obi and Chiefs ${ }^{12}$.

In Yoruba land, especially in the old Oyo Empire, the role of Iya-Afin was available for the women. Also the female Ogboni sit in the meeting of the Ogboni chiefs while the Iyalode sit with the Council of chiefs and wielded considerable economic and socio-political power. ${ }^{13}$ The posts of "Iyalode" and

\footnotetext{
${ }^{6}$ Gberevbie \& Oviasogie. (2013); Imam (1993).

${ }^{7}$ For this instances and more see Imam (1993) at 46.

${ }^{8}$ Ozo-Eson (2000) at 111.

${ }^{9}$ Akande (1999) at 102.

${ }^{10} \mathrm{Njoku}(1980)$ at 49.

11 Ibid.

${ }^{12}$ Imam (1993) at 46.

${ }^{13}$ Ozo-Eson (2000) at 111.
} 
"Iyalaje" serve as market women leaders and represent women in the chief court. ${ }^{14}$

In the Northern part, especially in Borno, women officials like Magira (Queen Mother) the Gumsu and the Magaram; the officials elder sister of the Mai (ruler), were said to have wielded enormous power and influence on sefuwa dynasty since its inception. ${ }^{15}$ In the same vein, in Ibobio, adult women attend Council meetings with their male counterparts ${ }^{16}$.

Notwithstanding the above given instances, some customary laws provide space for women participation in politics as absolute rulers. For instance, in Yoruba land, there was the female oba (king) in Ile-Ife, old Oyo kingdom, Ijesha and Ondo. ${ }^{17}$ In the Northern part, the position was not quite different as women played prominent roles in the socio-political affairs of the society. ${ }^{18}$ In some places some of them were great warriors and leaders. The Queen of Daura was at the helms of affairs and in a position to affect the course of development ${ }^{19}$. In Zazzau, succession to the throne of the monarch was made open to both male and female members of the ruling dynasty. This made the society unique among other Hausa states ${ }^{20}$. At least, two of their rulers were women, Bakwa Turunku and her daughter, Queen Amina. Amina'sister, Zaria also succeeded her as an absolute ruler of the community. ${ }^{21}$

Similarly, in the Eastern part, the leadership role played by Queen Kambasa of Bonny cannot be underestimated. She left a landmark of achievements and created a record for the women of that kingdom. ${ }^{22}$

The foregoing is an indication that Pre-colonial women were not passive but active in political participation as the Pre-Colonial era provided enabling environment for their participation. They have been participating in constructing and shaping of human societies and many were always ready to sacrifice themselves in the services of their various communities. The cases of Queen Amina of Zazzau, Moremi of Ile- Ife, Daurama of Daura, to mention a few, were still fresh in the memory of contemporary history of women in Nigeria. They were great women who played prominent and remarkable roles as well as sacrificed themselves for the continuous existence of their various communities. ${ }^{23}$

\footnotetext{
${ }^{14}$ Nnoli (2000) at 681.

${ }^{15} \mathrm{Saad}(1993)$ at 13.

${ }^{16}$ Imam (1993) at 46.

${ }^{17}$ Gberevbie \& Oviasogie (2013) at 46.

${ }^{18}$ Uchendu (1995) at 8.

${ }^{19}$ Awe (1992) at 7.

${ }^{20}$ Saad (1992) at 13.

${ }^{21}$ Ibid, at 14.

${ }^{22}$ Alagoa (1992) at 35.

${ }^{23}$ Ibid.
} 
Women Participation in the Nigerian Political Process during Colonial Period

The colonial period which began in 1900 changed the entire political structure laid down in the Pre- colonial Nigeria. The British brought about several changes to the African culture and value system, especially in the area of education, politics, social- economics as well as marital institution. Some of these changes however had negative impact on the hitherto rights of women in the Pre - colonial Nigeria, particularly, the political right. ${ }^{24}$ Right from this period, women began to experience oppression in all its ramifications and disguises. ${ }^{25}$ The policy of direct and indirect rule introduced by the Colonial masters to replace the already existing system of government formally marginalised women in the political scheme and they seem to have lost the power they possessed during the pre-colonial era. ${ }^{26}$ For instance, the British Legislative Council of colonial government had no record of a single woman appointed to represent the country throughout the colonial period. ${ }^{27}$ The Colonial government also abolished various female chiefs which were on ground in the Pre- Colonial period. By this, women chiefs lost their kingdoms and power they had possessed in the Pre-Colonial Period. Thus, this marks the beginning of serious political marginalisation and relegation of the political right of women, which they used to enjoy in the Pre- colonial days.

These relegation and marginalization of women in the political process in Nigeria led to mass protest in many part of Nigeria. The first was the Eastern women, which was popularly referred to as Aba riot of $1929 .{ }^{28}$ On the face of it, the Aba women riot was fought against the imposition of taxes and the system of colonial administration which could not be challenged by the menfolk. In effect however, it was a way by which women expressed their political right by employing new strategies to safeguard their interest in government and to ensure the kind of government they desired in their community. ${ }^{29}$ The colonial administrators underrated women in Nigeria and expect revolt, if at all, from the men, since African women were traditionally under the control of their husbands. The riot was therefore a challenge to colonial administrators as they were forced to replace their method of direct rule with the native laws which were enforced by male rulers, chiefs and elderly priests with regard to taxes and other levies. ${ }^{30}$ By this, the Igbo women achieved their immediate goals, even though this did not translate to their inclusion in the decision-making process of their community. They at least demonstrated the bravery and strength of their views on government administration and made the colonial administration aware of the female constituency. ${ }^{31}$ The riot has therefore been assessed in the contemporary days

\footnotetext{
${ }^{24}$ Njoku (1980) at 49-50.

25 Ibid.

${ }^{26}$ Akande, (1989) at 102

${ }^{27} \mathrm{Njoku}(1980)$ at 50.

${ }^{28}$ Nwakwo (2011).

${ }^{29}$ Akande (1989) at 102.

${ }^{30}$ Njoku (1980) at 42.

${ }^{31}$ Akande (1989) at 102.
} 
to have contributed to the national struggle in Nigeria. ${ }^{32}$ Similar protest was led by Mrs Olufunmilayo Ransome- Kuti in 1949 at Abeokuta, where women called for their right to vote. Most of the protests also rejected the actions of the Colonial government which relegated women to the background and shut them out of the active politics which they had been used to in the Pre-colonial period. At this period, women in many societies were still disenfranchised and only few of them were given political or administrative appointments. Thus in 1950 (Mrs) Oluwafunmilayo Ransome Kuti, Chief (Mrs) Margret Ekpo and Janet Mokolu were appointed into the House of Chiefs ${ }^{33}$. Also in 1953 and 1958, Mrs Margret Ekpo and Mrs Ekpo Young were among delegates appointed to attend the Constitutional Conferences between the British officials and Nigerian delegates in London to prepare for Nigeria's independence. They however attended in advisory capacity as they were not given chance to speak officially during the meeting. ${ }^{34}$ In effect, the exclusion and suppression of women from the political process and decision-making witnessed in the postcolonial Nigerian was heralded by colonization which treated women with little relevance. $^{35}$

\section{Legal Framework for the Right of Women to Participate in Politics and Governance}

The need for adequate representation for women in governance and political positions proceeds from the idea of gender equality, which is a movement for the empowerment of women and to rid the society of all forms of discrimination against women. Right against discrimination is a universal notion and has been enshrined in the constitution of many world nations, including Nigeria. Like any other human rights, right against discrimination on the basis of gender is inherent in women. It is neither vested nor conferred. Political roles are culturally or socially transmitted subject to changes from time to time. Women are equally endowed with the requisite resources to participate in governance and political positions as men. They have the intellect, energy and skill to fix many problems of today's world.

This segment therefore examines the political right of women under various human rights instruments as well as the status and relevance of these instruments to political rights of women in Nigeria. Various legislations with national, regional and international flavour guaranteed equal women participation in politics just like their men counterparts. These legislations are numerous to mention, thus some relevant few are considered subsequently.

a. International instruments

i. Universal Declaration of Human Rights (1948)

\footnotetext{
${ }^{32}$ Nwakwo (2011).

${ }^{33}$ Ibid.

${ }^{34}$ Olateru-Olagbegi \& Akiyode-Afolabi (2007).

${ }^{35}$ Nwakwo (2011) at 27.
} 
The Universal Declaration of Human Right (UDHR) ${ }^{36}$ is regarded as the mother of all other human rights conventions and legislations. It is the human right instrument which was proclaimed by a Universal International Organization. The General Assembly through the preamble to the instrument proclaims the instrument, among other things, to serve as the "common standard of achievement for all people and all nations"... "Similarly, the preamble contains the basic human rights which recognised "inherent dignity, equality and inalienable rights of all members of the human family." The human rights contained in this instrument can be broadly divided into two, namely; the civil and political rights which among other things contains the right of everyone to participate in the political affairs of his or her nation and the economic as well as social and cultural rights.

Article 21 of the instrument specifically guarantees the right of everyone to equally participate in the government of a country either directly or through freely chosen representative. Although the instrument is not legally binding, it is universally acceptable by all states and thus become a common reference in human rights for all nations. It is therefore incumbent upon all nations (Nigeria Inclusive) to promote and protect the human rights contained therein.

ii. The international Covenants on Civil, Political, Economic Social and Cultural Rights (1966)

Apart from the above instrument, other international instruments which are specifically made to complement and elaborate the content of the Universal Declaration are the International Covenant on Economic, Social and Cultural Rights $^{38}$ (ICESCR) and the International Covenant on Civil and Political Rights $(\mathrm{ICCPR})^{39}$ which were signed and ratified by Nigeria. ${ }^{40}$ However, the International Covenant on Civil and Political Rights (ICCPR) ${ }^{41}$ is the most relevant instrument to the discussion in this work. The ICCPR elaborates the political and civil rights contained under the Universal Declaration which include among others the right to equality before the law. While Article 1 of the two instruments respectively provide for the right of all persons to freely determine their political status among other things, Article 3 of the ICCPR specifically obliges state parties to ensure equal right of men and women to the enjoyment of all civil and political rights set forth in the instruments. Unlike the Universal Declaration, the two Conventions are legally binding on the state parties.

\footnotetext{
${ }^{36}$ Adopted 10 December 1948. G.A, Res. 217 A (iii), UN Doc. A/810 at 71 (1948).

${ }^{37}$ See the last Para of the Preamble to the Universal Declaration of Human Rights.

${ }^{38}$ Adopted and opened for signature, ratification and accession by the General Assembly Resolution 2200A(XXI) of $16^{\text {th }}$ December 1966 entry into force on $3^{\text {rd }}$ January 1976.

${ }^{39}$ Adopted and opened for signature, ratification and accession by the General Assembly Resolution 2200A(XXI) of $16^{\text {th }}$ December 1966 entry into force on $23^{\text {rd }}$ March 1976.

${ }^{40}$ Nigeria ratified the two Conventions on $29^{\text {th }}$ July 1993.

${ }^{41}$ Adopted and opened for signature, ratification and accession by the General Assembly Resolution 2200A(XXI) of $16^{\text {th }}$ December 1966 entry into force on $23^{\text {rd }}$ March 1976.
} 
iii. Convention on Elimination of All Forms of Discrimination against Women (CEDAW) 1979

In the like manner, the Convention on Elimination of All Forms of Discrimination against Women (CEDAW), otherwise referred to as the Women's Convention ${ }^{42}$ makes it mandatory for state parties to take appropriate measures to eliminate discrimination against women in political and public life of the country under its Article 7. It further mandates them to ensure that women are given equal right as their male gender to contest for all eligible posts $^{43}$ and to participate in formulation of government policy and the implementation thereof, and the right to hold public offices and perform all public functions at all levels of government. ${ }^{44}$ Their right to participate in NonGovernmental Organizations (NGOs) and associations concerned with the public and political life of the country is also guaranteed. ${ }^{45}$

In the same vein, Article 8 provides for equal opportunity of both males and females to represent their government at the international level and to participate in the work of international organizations. The Convention is a major milestone in the realization of human rights of women ${ }^{46}$ being the first international instrument to deal comprehensively with the condition of women. Nigeria signed and ratified the Convention; as such it is legally binding. ${ }^{47}$

\section{iv. Other international human rights instruments}

Other international human rights instruments that seek to protect the political right of women in Nigeria are the Convention on the Political Rights of Women ${ }^{48}$ and the Beijing Declaration and Platform for Action Fourth Conference on Women. ${ }^{49}$ The Convention entitles women to vote in all election on equal terms with men without any discrimination. ${ }^{50}$ It further provides for the right of women to hold public office and to exercise all public functions established by national law on equal terms with men without any discrimination. ${ }^{51}$ Similarly, the Beijing Declaration requires the empowerment and the full participation of women in all spheres of decision making on the basis of equality. ${ }^{52}$

\footnotetext{
${ }^{42}$ Adopted 18 Dec. 1979, entered into force 3 Sep. 1981, G.A Res. 34/180, 34 UN GAOR, supp. (No 46), UN. Doc. A/34/46, at 193 (1979), reprinted in 19 ILM 33 (1980).

${ }^{43}$ Art 7 (9)

${ }^{44} \operatorname{Art7}(\mathrm{b})$

${ }^{45}$ Art 7(c)

${ }^{46}$ Ogwu (1992).

${ }^{47}$ Nigeria signed in April 231984 and ratified in June 131985

${ }^{48}$ Adopted by the United Nations GA on $20^{\text {th }}$ December 1952 and opened for signature on $31^{\text {st }}$ March 1953 (U.N.T.S. 135). It entered into force July 1954.

${ }^{49}$ Beijing Declaration and Platform for Action Fourth Conference on Women, 15 September 1995, A/CONF.177/20(17October 1995) and A/CON,177/20/Add.1 (1995)

${ }^{50}$ Art 1.

${ }^{51}$ Art 2.

${ }^{52}$ See para 3
} 
b. Regional instruments

i. African Charter on Human and People Rights (1981) and its Protocol (2003)

At the regional level, the African Charter on Human and People Rights ${ }^{53}$ and its Protocol on Women's Rights, otherwise referred to as Maputo Protocol, ${ }^{54}$ equally guarantee the political rights of women in Nigeria. Article 13 of the African Charter guarantees the right of every citizen to participate in the government of his country either directly or through the freely chosen representative in accordance with the law. Nigeria ratified and adopted the provisions of this Charter, and in addition domesticates the provisions of the Charter in its Constitution. ${ }^{55}$

In the same token, the Protocol to the Charter ${ }^{56}$ guarantees equal participation of women in political life of their countries through affirmative action, enabling national legislation and other measures. ${ }^{57}$ It also guarantees the right of women to participate in all election without any discrimination, ${ }^{58}$ the right to be represented equally at all levels with men in all electoral processes ${ }^{59}$ and be equal partners with men at all levels of development and implementation of state policies and development programs. ${ }^{60}$ Nigeria also signed and ratified this instrument.

ii. Implementation of the provisions of the international and regional instruments

From the analysis of the legal instruments set out in this segment, Nigeria was noted to have adopted and even ratified most of them. However, none of these instruments has been domesticated in its local laws except the provisions of the African Charter, which was domesticated in Nigeria under the authority of Section 12 (1) of the 1999 Constitution. Pursuant to the Section, the African Charter on Human and People's Right (Ratification and Enforcement) Act Cap 10 Laws of the Federation of Nigeria was passed. The Act enables Nigeria to give effect to the provision of the Charter and as such, the African Charter was adopted into domestic law. ${ }^{61}$ Consequently, other international and regional instruments do not carry the same effect as the African Charter in Nigeria. Hence they do not form part of Nigerian laws

\footnotetext{
53 Adopted 27 June 1981, entered into force 21 Oct. 1986, O.A.U. Doc. CAB/LEG/67/3/Rev.5, reprinted in ILM 58 (1982); 7 HRLJ 403 (1986). Nigeria signed the document on $31^{\text {st }}$ August, 1982 and ratified on $22^{\text {nd }}$ July, 1983.

${ }^{54}$ Adopted by the Conference of Heads of State and Government Maputo-Mozambique 11 July 2003, came into force on 25 November, 2005. Nigeria signed the document on $16^{\text {th }}$ December, 2003 and ratified on 16 December, 2004.

${ }_{55}^{5}$ Sec 121999 Constitution of the Federal Republic of Nigeria.

${ }^{56}$ See Art 9 generally.

${ }^{57}$ Art 9(1).

${ }^{58}$ Art 9(1) (a).

${ }^{59}$ Art 9(1) (b).

${ }^{60}$ Art 9(1) (c).

${ }^{61}$ See the provision of Section 1 of the Act.
} 
The above position has further being reinforced by the Supreme Court when it held that treaties do not constitute part of the law of the land merely by virtue of their adoption and ratification. Otherwise, the executive will be seen as law making body if mere ratification by the executive will render the treaty directly enforceable under domestic law. This argument forms the basis of judgment in the case of African Reinsurance Corporation v. Fantaye. ${ }^{62}$ This paper therefore argues that non-domestication of these instruments is one of the factors responsible for the failure of the country to respect and observe her obligations under the instruments, especially as it relates to the protection and advancement of women's rights in Nigeria.

It should be noted that this work is not oblivious of the argument that when a treaty is ratified by a state such treaty becomes a binding international obligation in that state, ${ }^{63}$ and a party to a treaty is under an obligation to ensure that its national law conforms to its international obligation. ${ }^{64}$ The argument concludes that a state party cannot implore the provisions of its Constitution to avoid its obligation under the international law. ${ }^{65}$ More importantly, it was argued that the entire Universal Declaration embodies customary international law, which though not binding on any state, it reflects the ideals held by the International Community. ${ }^{66}$ As plausible as this argument may be, it cannot be equated with the Supreme Court decision on this matter. Notwithstanding the merit of the argument, it has no force of law but the Supreme Court decision does. Then, the question that is begging for answer is "since the instruments are not domesticated in the Nigeria's Municipal law, of what relevance are these laws to the human rights of women in general and on their political rights in particular? Even the Africa Charter, which has been domesticated in the municipal law and which, contains similar rights with the provisions of other international and regional laws could not impact much on the political right of women due to various socio-cultural challenges confronting women in Nigeria. This challenges form the basis of discussion in the later segment of this work.

c. National instruments

i. Constitution of the Federal Republic of Nigeria (1999)

Following Nigeria's Independence in 1960, human rights issues began to manifest in the Nigerian Constitutions. The two Constitutions of the first Republic were replicated with human rights provisions. The Constitutions of the Second, Third and Fourth republic have more elaborate human rights provisions as well. For example, they provide for civil and political rights in chapter four while they provide for social and economic rights in Chapter two. Specifically, Section 15 of the 1999 Constitution of the Federal Republic of Nigeria provides for the political objectives of the state when it provides under section 15(2) that

\footnotetext{
${ }^{62}$ (1986) 3(NWLR) (Pt. 31) 811 at 834.

${ }^{63} \mathrm{Ogbu}(1999)$ at 47.

${ }^{64}$ Ibid, at 61 .

65 Ibid, at 64.

${ }^{66}$ Ladan (1999) at 56.
} 
the national integration of Nigeria shall be encouraged and that discrimination on the grounds of sex, place of origin, religion, status, ethnic or linguistic association or ties is prohibited. This section should be read in conjunction with Section 14 of the same Constitution which provides that Nigeria state should be based on the principle of democracy and social justice. The section goes further to provide that Sovereignty of Nigeria state belong to the people of Nigeria, ${ }^{67}$ (male and female) alike ${ }^{68}$. It is from the people that the government through the Constitution derives all its powers and authority to rule. In addition to the above, the provision goes further to provide that the participation by the people in their government shall be ensured in accordance with the provisions of the Constitution. ${ }^{69}$ The phrase 'in accordance with the Constitution' connotes men and women in Nigeria are entitled to participate in the government since the Constitution itself prohibits discrimination. ${ }^{70}$

The 1999 Constitution in conjunction with the relevant portion of the African Charter provide for equal political opportunity for men and women without discrimination. Despite these provisions, the legislative and executive arms of government in Nigeria are dominated by men. Unlike the position in the Pre- Colonial period the political participation of women in Nigeria has been on the decline. ${ }^{71}$ All efforts made by women and women's rights activists to improve the situation have not yielded much result.

\section{ii National Gender Policy (2006)}

The National Gender Policy aims to promote gender-sensitive and gender responsible culture in policy planning and national development and addresses the systematic structure of inequalities existing between men and women in Nigeria, while still upholding the fundamental difference between them. ${ }^{72}$ It replaces the National policy on women which was not capable of challenging the structure of gender inequality already existing in Nigeria. The goal of the Policy is to "build a just society devoid of discrimination, harness the full potential of all social groups regardless of sex..."73 Thus one of the key points of the Policy is promotion and protection of human rights, social justice and equity. Among the critical areas of gender disparity which the Policy focuses its attention is the equitable representation of women in policy and decisionmaking of the country. Thus the policy aims to ensure equal opportunity for men and women in government and also addresses the already imbalance of women representation in country governance and decision making. Part of the efforts made by women activists was the affirmative action which gives 30 percent of the legislative and executive arms of government to women. This is however not the case in reality as women are not giving meaningful opportunity to

\footnotetext{
${ }^{67}$ Sec 14(a) 1999 Constitution of the Federal Republic of Nigeria.

${ }^{68}$ Emphasis mine

${ }^{69}$ Sec 14(c) 1999 Constitution of the Federal Republic of Nigeria

${ }^{70} \mathrm{Sec} 421999$ Constitution of the Federal Republic of Nigeria.

${ }^{71}$ Imam (1993) at 46.

${ }^{72}$ Kura \& Yero (2013).

${ }^{73}$ See para 2.3 of the Policy
} 
participate in the political parties which is the only platform by which anyone can be elected to a governance position in the country. The few instances that feature women in governance and decision - making were through appointments. Despite this Policy in the country, the three tiers of government is still much dominated by men with slight improvement in 2003 and 2015 general election (as discussed later in this paper). Notwithstanding that improvement, women are still grossly under-represented in the affairs of the state where they constitute half of the total population.

\section{Political Participation of Women in Post- Colonial Period}

To examine the political participation of women in this period, an overall political situation in the country must be considered since independence both in the Military and Civilian administrations. The reason for consideration of the two administrations is born out of the fact that 29 out of 55 years of the nation's independence was characterised with various military regimes. It should be recalled that the military regimes are globally acclaimed to be maledominated regimes. ${ }^{74}$ It is not in doubt that there are enough extant legislations upon which women can rely on to achieve their political desires as enumerated earlier. These legislations are the foundations upon which the subsequent administrations ought to have built on in allowing women to hold some of the key leadership positions of the country. To what extent have those administrations uphold this laudable tenet? The answer to this poser is deducible in the next segment of this work.

i. Political participation of women under the military regime

Less than 7 years after independence of 1960, Nigeria witnessed the military at the helms of affairs. This lasted for a period of 29 years with interjection of civilian administration between 1979 and 1983. The uninterrupted military rule from 1966 to 1979 with just a brief period of civil rule between 1979 and 1983 further resulted in perpetual exclusion of women in political arena and the decision-making bodies of the country. ${ }^{75}$ By and large, Nigerian women were not in the hierarchy of the supreme Military Ruling Council, and therefore could not be part of members of the highest legislative and executive bodies which were usually combined during the military era. ${ }^{76}$ Similar experience was witnessed at the states levels under military leadership.

Between 1984 and 1985, there was however a tidal change in the appointment of female to the military cabinet during the administration of General Muhamadu Buhari as the then head of the military administration. It was on record that there was a direction that at least, one woman should be appointed in the Executive Council of each state. All states complied with the directives to the

\footnotetext{
${ }^{74}$ Nwakwo (2011).

${ }^{75}$ Olateru-Olagbegi \& Akiyode-Afolabi (2007).

${ }^{76}$ Imam (1993) at 46. Ezeilo (2001) at 25.
} 
extent that some states had two or three women in their cabinets. ${ }^{77}$ Similarly, the administration under the leadership of General Ibrahim- Badamosi Babangida in the early 1990s followed its predecessor by appointing two women deputy governors; Alhaja Lateefat Okunnu of Lagos State and Mrs Pamela Sadauki of Kaduna State out of 36 states. This represent 5.6 percent. ${ }^{78}$ Also, quite a number of female Ministers emerged during the administration of late General Sanni Abacha. These include Chief (Mrs) Onikepo Akande and Ambassador Judith Attah. ${ }^{79}$ It was also on record that out of 361 males mandated to draft a new Constitution during Abacha regime, only eight were females ${ }^{80}$. This was said to be an improvement over General Olusegun Obasanjo's 1976 - 79 administration. It would be recalled that there was no single woman among the 40 wise-men charged with the responsibility of drafting a new Constitution in $1978 .{ }^{81}$ Also following the foot print of his predecessors, the military administration under the leadership of General Abdulsalam Abubakar witnessed the appointment of two women; Chief (Mrs) Onikepo Akande as Minister for Commerce and Dr Laraba Gambo Abdullahi as Minister of Women Affairs at the federal cabinet. If not for these, the political landscape of Nigeria during the military period would have featured a total male dominance. ${ }^{82}$

By and large, the military failed to see any justification for the inclusion of women into their cabinet. Thus, women are grossly under-represented at the federal and state military cabinet in the successive military administration of Nigeria. This may not be far from the fact that there were few women found in the military profession. The consequence of this however, was that major policy decisions of the country were taken without female representation. This is even if the decisions and policies directly affect women ${ }^{83}$ and the girl-child.

\section{ii. Political participation of women under the civilian regime}

Representation of women in governance and decision-making of the country is not much different from what is obtained during the military regime. In this sphere also, women have not been adequately compensated in terms of appointment to the state and federal cabinet notwithstanding the supports they render to various political parties. For instance, record had it that there is the appointment of only one woman -Mrs Wuraola Esan out of 36 members of post-independence senate. By this appointment, she emerged the first female member of the federal cabinet. The story was however not the same at the House of Representative. Out of the 32 members of post-independence House of Representatives there was no single woman representation. Following the

\footnotetext{
${ }^{77}$ Nwakwo (2011).

${ }^{78}$ Agbaegbu (2000) at 17.

${ }^{79}$ Nwakwo (2011).

${ }^{80}$ Ezeilo (2001) at 22.

81 Ibid.

${ }^{82}$ Agbaegbu (2000) at 17.

${ }^{83}$ Yusuf (1993) at 5.
} 
same trend, neither the federal government nor the three regional governments appointed at least a woman to their cabinets. ${ }^{84}$

In the 1961 general election, two women; Margret Ekpo and Janet Mokolu won seats to the Eastern House of Assembly. ${ }^{85}$ The third person; Mrs Ekpo Young however won through by-election into the same House in $1963 .^{86}$ In 1964, Mrs Benice Kerry was nominated by the newly created Mid- Western Region to join Mrs Wuraola Esan. ${ }^{87}$ However, in reaction to the exclusion of women in politics and decision-making of the country, five women were appointed to the Constituent Assembly out of 250 members $^{88}$. The five women though smaller in number but made a remarkable achievements in the history of women's participation in politics in Nigeria ${ }^{89}$. Their landmark achievement was the inclusion of the non-discriminatory clause in the 1979 Constitution. ${ }^{90}$ The clause, till date serves as one of the major pillars upon which the protection of women's rights rest in Nigeria. ${ }^{91}$ It is noteworthy that at this period, women in the North were still disenfranchised. Hence, prominent woman political figures like Hajia Gambo Sawaba could not vote and be voted for until 1979..$^{92}$

During the 1979 general election which ushered in Second Republic, no woman contested for the posts of President and Governor. However, four contested for Senate and none was elected out of 45 members. There was a slight difference at the House of Representatives, there were three female out of 450 members ${ }^{93}$. At the state level however, there were five women members of the various Houses of Assembly across the nation. Similarly, the federal cabinet witnessed the appointment of two female Ministers; Chief (Mrs) Janet Akinrinade; the Minister for Internal Affairs, and Mrs Adenike Ebun Oyagbola; the Minister for National Planning. The period also witnessed the appointment of one female Permanent Secretary; Mrs Francisca Yetunde Emmanuel. She was first in the Federal Ministry of Establishment and later in the Federal Ministry of Health. ${ }^{94}$ Most state also had at least one female Commissioner.

The same trend followed in the 1983 general election (Third Republic). This is because women did not get commensurate number of seats in the positions of authorities and responsibilities. ${ }^{95}$ This period saw only one woman -Ms

\footnotetext{
${ }^{84}$ Nwakwo (2011) at 27.

${ }^{85}$ Ibid.

${ }^{86}$ Olateru-Olagbegi \& Akiyode-Afolabi (2007) Nwakwo (2011) at 27.

${ }^{87}$ Ibid.

${ }^{88}$ Agbaegbu (2000) at 17.

${ }^{89}$ Ibid.

${ }^{90}$ The right freedom from discrimination was first included in the 1979 Constitution due to the few number of women present at the Constituent Assembly. It was a landmark achievement which remain fresh in the minds of women in Nigeria generally and women's rights activists in particular.

${ }^{91}$ See the provision of Section 42 of the Constitution of the Federal Republic of Nigeria.

${ }^{92}$ Agbaegbu (2000) at 17.

${ }^{93}$ Shettima (1993) at 26.

${ }^{94}$ Agbaegbu (2000) at 17.

${ }^{95}$ Ibid.
} 
Franca Afegbua, out of a total of 45 members of the Senate. On the other hand, the House of Representatives had eight women out of a total of 360 members. ${ }^{96}$ However, this regime was short lived as it lasted only three months. The Interim government headed by Chief Ernest Shonekan witnessed only one woman -Otunba Kuforiji Olubi, out of the 32 members. The period also witnessed the appointment of two women to the Federal cabinet. They are Mrs Mobolaji Osomo who was appointed as the Minister for Establishment and Mrs Ada Adogu who was appointed as the Junior Minister for Agriculture. ${ }^{97}$

According to a data presented by Bisi Olateru-olagbegi and Biola Akinyode ${ }^{98}$ and a research carried out by Joy Ezeilo ${ }^{99}$, the 1999/2003 general elections, (Fourth Republic) witnessed the election of only one woman Speaker out of 36 across the nation. The number represents 2.7 percent of the total members. The woman was said to be the first woman to occupy such a position. ${ }^{100} \mathrm{~A}$ total number of 31 women were elected at the various Houses of Assembly in all 36 states of the federation. Similarly, only one woman deputy governor was elected out of a total number of 36. This also represents 2.7 percent of the total number. At the Local Government level, out of 774 elected chairpersons, only one was a woman. This number represents 1.2 percent of the total number. In the like manner, out of 8810 Councillors elected, only 143 were women. This number represents 1.2 percent.

Moving up to the Senate, women won only three seats out of 109 available seats which represents 1.2 percent of the total member. Women performed considerably well when compared with previous years at the House of Representatives. They were able to occupy 13 seats out of a total of 360 available seats. ${ }^{101}$ By and large, the government of President Obasanjo redressed this position and appointed nine women as Ministers and advisers out of the total of 44 appointments made by his administration. With this appointment women held a total of 22.5 percent of all the appointments of the Federal Government. $^{102}$ Notwithstanding this appointment, Joy Ezeilo was of the opinion that the Ministers' list showed that less than ten percent of them were women, while less than five percent were Special Advisers or Assistants. In all, only ten percent of women were in power or in positions of decision-making in the country. ${ }^{103}$

All in all, out of a total of 11,881 contestant during this period, only 631 women contested and 181 won $^{104}$. This represents 1.62 percent of the total number in a country where women constitute almost half of its total population ${ }^{105}$.

\footnotetext{
${ }^{96}$ Shettima (1993) at 26.

${ }^{97}$ Nwakwo (2011).

${ }^{98}$ Olateru-Olagbegi \& Akiyode-Afolabi (2007).

${ }^{99}$ Ezeilo (2001) at 23-24.

${ }^{100}$ Ibid.

101 Ibid.

${ }^{102}$ Olateru-Olagbegi \& Akiyode-Afolabi (2007).

${ }^{103}$ Ezeilo (2001) at 24

${ }^{104}$ Ibid at 23 .

${ }^{105} 2006$ Population census official gazette available at http://www.state.gov.ng/connection/ pdp2006.pdf. By that result, the total number of women in the country is $68,293,638(48.8 \%)$
} 
Although the period might have witnessed an increase in the level of participation of women in politics and decision-making, this increase was only noticeable in the appointive positions as many who contested were never elected. ${ }^{106}$ This may not be as a result of marginalization alone but due to some socio- cultural practices which subjugate women and which have placed women at a disadvantage position when it comes to contesting with the male. In many instances. Some of these practices forms the basis of discussion in another segment in this paper.

The 2003 general election experienced a slight increase in the number of women in elective positions. ${ }^{107}$ This was however attributed to the fact that there were more political parties registered at that period. ${ }^{108}$ There were also more women aspirants because the political parties decided to waive the payment of registration levies for women political aspirants. ${ }^{109}$ Despite these factors, the number of women who sailed through the primaries was still very few. This resulted into election ${ }^{110}$ on of lower number of women at political helms of affair in 2003. ${ }^{111}$ Notwithstanding this, the period witnessed the election of two women deputy governors; ${ }^{112}$ Erelu-Obada of Osun State and Senator Kofoworola Burknor-Akerele of Lagos state. The period also witnessed not only an increase in the number of women appointees, but also recorded women holding influential positions at the key ministries, such as Ministries of Finance, Housing ${ }^{113}$ and Education. Also at the Legislative House, there were four women out of 109 members of the Senate. While there were 23 women out of 360 members of House of Representatives. ${ }^{114}$ This dispensation also witnessed a woman Speaker, Deputy Speakers and Commissioners at various state levels. ${ }^{115}$ Thus, the Data presented above is a clear indication that the 1999 and 2003 general elections recorded some improvements over the previous political dispensations.

The above situation was however not the same at the state and local government levels during the above mentioned regimes. Some states like Osun did not appoint any female Commissioner throughout the four-year term ${ }^{116}$. The effect of this is that a male Commissioner superintended over the Ministry of Women Affairs, which was established for the purpose of boosting the welfare of women. The effect of this is that decisions affecting women, children and families at large which is the area of expertise of women are taken without

out of the total number of 140, 0003,542. By 2009 result, women accounted for $50 \%$ of the total population.

${ }^{106}$ Arowolo (2010) at 581.

${ }^{107}$ Olateru-Olagbegi \& Akinyode-Afolabi (2007).

108 The total numbers of registered parties were 28 in number.

109 This used to be one of the challenges hindering the political participation of women in politics.

${ }^{110}$ Olateru- Olagbegi \& Akinyode-Afolabi (2007).

${ }^{111}$ Ibid.

${ }^{112}$ Nwakwo (2011); Olateru-Olagbegi \& Akinyode-Afolabi (2007).

113 Ibid.

${ }^{114}$ Ezeilo (2001) at 23.

115 Olateru-Olagbegi \& Akinyode-Afolabi (2007).

${ }^{116}$ Ibid. 
the involvement of women who are actually the stakeholders. It is this domination of positions that angered some women groups which made them to have resorted to legal actions to obtain a concession in Enugu State. The women in this state made an issue of their exclusion in the State Executive Council by instituting legal actions against Governor Chimaroke Nnamani of Enugu state, before one of them was appointed a Commissioner. ${ }^{117}$

In the 2007 general elections, women did not perform significantly different from the 2003 elections. In terms of governance and decision-making, women are still far behind. Although the support for women candidatures was massive from various women group, ${ }^{118}$ yet there was no corresponding improvement in the election of women into public offices. Out of 109 senators in the National Assembly, only nine are female, while out of 360 members of House of Representative, only 27 are female. ${ }^{119}$ The dispensation also witnessed seven deputy governors. ${ }^{120}$ Therefore according to Nwakwo, the highest representation women have had in the Federal executive council is 20 percent in 2003-2007 dispensation. Similarly, out of 990 members of state Houses of Assembly, only 54 are women. ${ }^{121}$ The only first female Governor which emerged during this dispensation, Dame Virgy Etiaba was functional as Anambra state governor for six months, following the impeachment of her boss, Governor Peter Obi, on November, 2, 2006. ${ }^{122}$ The above data therefore tend to reinforce the wide spread concern of human rights activists that women are grossly under-represented in the legislative and executive council of the nation. This is however not denying the fact that some appointments were given to some of them.

The 2011 election witnessed eight percent of women in political offices. Thus out of a total number of 10,000 male candidates across the political parties (90.9 percent), only 909 were female (9.1 percent). ${ }^{123}$ Therefore, the number of women in politics and decision-making positions today fall short of expectations considering their numerical strength in the state. The administration witnessed an appreciable number of women holding key positions in governance and decision-making. There were 13 women Ministers out of a total of 32 and four Special Advisers out of 18. This represents a total of 31 percent and 23 percent respectively as against 30 percent Affirmative Action in favour of women. ${ }^{124}$ Also at the legislative level, the dispensation witnessed seven women out of 109 Senators and 25 out of 360 members of House of Representatives (6.8 percent). ${ }^{125}$ At the state Houses of Assembly, there were

\footnotetext{
${ }^{117}$ Agbaegbu (2000) at 17

118'2007 Election how did it fear women' http://www.Knowpolitics.org, assessed on January 12,2012

${ }^{119}$ Kolade (2015).

${ }^{120}$ Nwakwo (2011).

${ }^{121}$ Kolade (2015).

122 Ibid.

${ }^{123} \mathrm{http}$;// agora.nigeriaelection.com.[12 January 2012].

${ }^{124}$ Idike (2015) at 160

${ }^{125}$ Gberevbie \& Oviasogie (2011) at 90
} 
68 women out of a total of 990 across the country. ${ }^{126}$ There was no single woman local government chairperson and councillors out of a number of 740 and 6368 respectively. ${ }^{127}$ Thus women were only able to secure higher percentage in appointive positions as opposed to elective positions. With the above situation, Nigerian women are now sure of appointive positions even when they are knock out during general election.

The administration also witnessed a total of ten women Ambassadors. Similar achievement was recorded at the judicial level. With these, Nigerian women have attained an unprecedented highest level of participation in governance and decision-making of the country. Furthermore, there have been remarkable successes in creating awareness on the participation of women in politics. Not only that a Political Trust Fund was created for women political aspirants, its implementation of Gender Policy equally witnessed an increased from 10 percent in 2011 to 33 percent in 2013. ${ }^{128}$

To this end, scholars have observed that Nigerian women never had a pride of seat in governance than in Jonathan's administration. ${ }^{129}$ The administration was the first to produce first woman Chief Justice of Nigeria, first woman Petroleum Minister and many other first attributed to women in the history of leadership and governance in Nigeria. As such the administration was said to be the most gender sensitive administration in Nigeria so far. ${ }^{130}$ The improvement in the appointment of women to public office could be attributed to the promise made by President Jonathan during the 2011 campaign. It was on record that the then President promised women to pursue the National Gender Policy of appointment of more women into his cabinet if elected. Hence, more appointment for women at this period. ${ }^{131}$ Similar promise forms the basis of his campaign during the preparation for 2015 general election which was lost to the incumbent president, General Muhammad Buhari (rtd). With this position, it is doubtful if the administration is truly gender sensitive as proclaimed by some academic scholars.

The 2015 just concluded election did present a better picture than it used to be in term of women representation. There are 14 female members of House of Representative out of 306 and only eight members of Senate out of $109^{132}$. Also out of 36 Ministers appointed by President Muhammadu Buhari, only 6 are women (16 percent). The only woman gubernatorial candidate in Taraba state, Senator Aisha Jummai Al-Hasan lost the election to a male counterpart. This situation dashed the hope of women in Nigeria who have been expecting the emergence of first elected female governor in Nigeria. However, there

\footnotetext{
126 Ibid.

127 Ibid.

${ }^{128}$ Idike (2015) at 160

${ }^{129}$ Ibid.

${ }^{130}$ Ibid.

${ }^{131}$ Gberevbie \& Oviasogie (2013) at 90

${ }^{132}$ Akpan (2015).
} 
emerged at least four women deputy governors. ${ }^{133}$ Similarly, her counterpart in Akwa-Ibom was not able to breakthrough in the male dominated system. ${ }^{134}$

The analysis presented above indicates that Nigerian women have not been fared in terms of representation in top public offices. This is in sharp contrast with situation in other part of African countries. For instance, in Rwanda, women constitutes 61 out of 106 members of the parliament (58 percent). ${ }^{135}$ In Senegal, there are 65 out of 150 members of the parliament (43 percent), while in Nigeria, women makes up 22 out of 415 members of the parliament (5.3 percent) as at 2015. All these realities exist despite the National Gender Policy, which promises to support women to achieve 30 percent of the legislative and executive positions in Nigeria.

However, it is generally accepted that no matter the percentage of women in the political activities of the country today, women are still under-represented when compared with the percentage of their population. And as expected, they had advanced many reasons which have contributed to their non-representation or under-representation in the policy and decision making of the country. Some of these reasons are the subject of the next segment of this work.

\section{Challenges Facing Women Participation in Politics}

The under-representation of women in Nigeria politics today was not unconnected with certain socio-cultural, religious and legal factors. These factors therefore, as will be analysed, constitute impediments to women's active participation in politics and subsequently to holding public offices in the country.

\section{i. Cultural challenges}

Culturally, in almost all parts of Nigeria, certain customary sayings are common. The sayings include "Women should be seen and not heard", "a woman's place is in the home" or "Women's office is the kitchen." The negative implications of these sayings are far reaching. It culturally implies that women are not supposed to partake in politics. It further portend that the position of women is predominantly restricted to home affairs. The cumulative effect of this is that women in politics are out of place and as such should retreat and desist from participating in politics. Those women who paid no attention to the cultural restriction are seen as deviant and as such are regarded as women of no family nobility. Interestingly, however, such "deviants" are later celebrated when they are successful in politics and having wrenched themselves out of the shackles of cultural stigma. ${ }^{136}$ The cases in point include the likes of Senator Ita Giwa, Alhaja Lateefat Okunnu, of Lagos State, Erelu -

\footnotetext{
${ }^{133}$ Ibid.

134 Ibid.

${ }^{135}$ Sogbesan (2015).

${ }^{136}$ Yusuf (1993) at 5.
} 
Obada of Osun State and many other women who were made Deputy Governors of their States and have performed excellently in their various positions.

Although the Pre-Colonial women as seen above in some communities were absolute rulers and at times ruled in conjunction with their male counterparts. The case is however different, as the contemporary politics is more fashionable than that of Pre-colonial period. Apart from this, the Precolonial women never contested against their male counterparts but were rather honoured with such positions and were not giving opportunity to discuss with the male in some circumstances Evidences have shown above that the power they exercised then was culturally lower to those of their male colleagues.

\section{ii. Educational challenges}

Another factor which has militated against women participation in Nigerian political process is inadequate education cum the dwindling economic crises. To garner necessary skills involved in the art of politics, there should be sound educational training. Regrettably, sound educational training eludes most women in Nigeria. The common reason to all parts of Nigeria seems to be huge economic crisis in the country. Poverty and ignorance prevent many parents from send their children to school and the female children are the worst hit. This is because, many a time, they were withdrawn from school by their parents to hawk for the survival of their male counterparts who are in school. ${ }^{137}$ The society prefers to invest in male's education in order to earn greater claim to their income. ${ }^{138}$ The effect of this is that female children are inadequately prepared for politics and as such not made available in times of need for politics and decision making.

Other different reasons account for inadequate women education in Nigeria. These reasons differ from place to place in Nigeria. For example, in the Northern and some parts of Southern Nigeria, female child education is often interrupted with marriage. This is so even at the time such a child does not understand what marriage is all about. A girl of this circumstance, whose educational up bring has been exchanged for marriage can never be ready to be involved in modern politicking when especially the minimum educational qualification is set by law. ${ }^{139}$ This problem persists despite various legislations prohibiting the act and directing the victims of such act to be returned back to school.

The reason for inadequate education and indeed participation of women in politics is slightly different in the Eastern part of Nigeria. In the Eastern states, the level of education of a girl determines the amount of the bride price to be paid by the groom's family. A girl under this situation has been priced and sold like a commodity and can no longer claim any right to participate in politics and decision-making of her country. ${ }^{140}$ Even though she is educated to the

\footnotetext{
${ }^{137}$ Okoye (1993) at 20-21. Ogwu (1992) at $143-144$

${ }^{138}$ Bozimo (2000) at 1

${ }^{139} \mathrm{Sec} 65$ (2) 1999 Constitution of the Federal Republic of Nigeria.

${ }^{140}$ Okoye (1993) at 22. See also Ogwu (1992) at 144.
} 
minimum level required by the Constitution, she is under absolute control of her husband who had "purchased" her with huge amount of money. Such husband is not always ready to release her to participate in politics because the circumstances surrounding her marriage subjected her to the whims and caprices of her husband. The above is irrespective of the fact that the law has put a ceiling on the amount of money that could be received as bride price in this part of Nigeria. The implementation of such law is almost impossible because parents of the affected female/women are wallowing in abject poverty and the only saving grace is to "sell" their female/women children in the name of marriage. ${ }^{141}$

\section{iii. Financial challenges}

Lack of capital and inability to raise it for political campaigns has also been identified as factor militating against women's participation in Nigerian political process. Generally all over the world, political campaign is very expensive -in fact it has been regarded as a capital intensive project. ${ }^{142}$ It is peculiarly expensive in Nigeria because money, rather than merits, determines who holds and occupies what political office. Since women are not usually in the lucrative professions or businesses due to their low level of education, it apparently becomes difficult for them to afford or raise the kind of huge amount of money required for Nigerian politics. This is unlike their male counterparts who could raise money to finance voters' mobilization.

\section{iii. Constitutional challenges}

Legally, the Nigerian 1999 Constitution which is the Grundnorm of the nation has been regarded as an instrument which aid political inequality between men and women instead of protecting the interest of women. ${ }^{143}$ In her critique of the Constitution on gender issues, Akande is of the firm view that the Constitution is gender insensitive and therefore violates the rights and privileges of women. ${ }^{144}$ She further contends that although women constitute $49.6 \%{ }^{145}$ of the total population and were responsible for 27 million votes during the 1999/2003 elections, yet women had no specific protected rights of political participation in Constitution. ${ }^{146}$ She further confirms that Section 42 of the 1999 Constitution, which prohibits discrimination on the ground of sex,

\footnotetext{
${ }^{141}$ Okoye (1993) at 22.

${ }^{142}$ Klenke (2011) at 49.

143 Agbaegbu (2000) at 17

${ }^{144}$ Ibid.

145 She based her argument on 2006 Census result which stipulates that women constitute $48.78 \%$ of the total population.

${ }^{146}$ There is no other provision apart from Section 42 dealing with the issue or rights of women. Unfortunately, Chapter II of the constitution which encompasses other rights is made not justiciable by the Constitution itself. See Sec 6(6) (c) of the 1999 Constitution of the Federal Republic of Nigeria.
} 
was a disadvantage to women in Nigeria. ${ }^{147}$ It provides School Certificate as minimum educational requirement for participation in meaningful politics. And off course, less than half of women can attain this based on the factors earlier discussed on female children education. The overall effect is that the Constitution stands as an obstacle to the realisation of women's political ambitions

\section{v. Political challenges}

Again, the style of politics and politicking in Nigeria also hinders effective participation of women in politics in Nigeria. In most cases, major political decisions on who contests for which office popularly referred to "political deal" are struck in odd places and at odd hours -Hotels and midnight till down. This is a period that is most inconvenient, uncomfortable and unsafe for women to participate in such deals. ${ }^{148}$ The societal expectation is that women should not be seen in most of the places and time where the "deals" are to be perfected. ${ }^{149}$ This is because it falls within the time women are expected to perform their major family responsibilities in order to meet their traditional role of women as mothers and wives. The overall effect therefore is that women are exempted from such "deals." That is, decisions regarding who occupies what political offices are taken in their absence and it in turn hinder their full participation in politics. ${ }^{150}$

\section{Concluding Remarks}

This paper critically assesses the involvement of women in politics in Nigeria. The assessment revealed that from pre-colonial period to post-colonial period, there have been various degrees of women involvement and participation in politics. The assessment also showed that women were actively involved in politics in pre-colonial period but such involvement was however curtailed in the colonial period. Apparently, there was an improvement in women participation in politics in Post- Colonial period but this improvement is not commensurate to the total number of women in Nigeria.

The paper further examines the challenges confronting women in politics and decision-making of the country. The examination indicates that multitude of factors ranging from social, political, economic to legal are responsible for the low-representation or under- representation of women in politics and decision making. It also comes to light that there is nothing in the constitution which excludes women from participating in politics, yet they are grossly under-represented in politics and decision making because no special provision is available to them considering their peculiar situations. Therefore, elimination of these socio-cultural barriers will automatically lead to development of

\footnotetext{
${ }^{147}$ Agbaegbu (2000) at 17

${ }^{148}$ Akande (1999) at 109.

149 Ibid.

${ }^{150}$ Klenke (2011) at 51.
} 
women, especially, in the areas of politics and decision-making of the country. Apart from this, it will also promote gender equality and earn women their rightful recognition as key players and thus enable them to further contribute meaningfully to the development of the nation where they constitute half of the total population.

The paper also critiques some national, regional and international legislations dealing with human rights in general and women's political rights in particular. The result shows that rather than inhibiting women's participation in politics, the theme of the legislations enhances, encourages and promotes women's participation in political process and decision making. The theme does not in any way preclude women from participating in active politics worldwide. Rather, it discourages any form of discrimination against women in all human endeavours. Thus, those legislations and others not discussed in this paper should be seen as weapon for women's participation in politics and decision making in Nigeria.

From the above pedestrian, it is logical to say that the Nigerian women stand on the same pedestal with their men counterpart if given the opportunity to perform and display their talents. However, it seems that the political game of Nigeria has been exclusively reserved for men due to many reasons some of which have been highlighted. And as such the inevitable conclusion is that Nigerian women are less politically active. ${ }^{151}$ Many Feminists and Women Activists have contended that Nigerian men profit from this lop-sidedness and will therefore wish that the status quo ante is maintained. This again explains why no serious attention is paid to reasons why there are few women in the Nigerian politics ${ }^{152}$ despite their numeric strength. Therefore, the thesis of this paper is that women should be encouraged and enlightened to appreciate the fact that the game of politics is for all if not for women more than men. After all, the golden adage is "progress for women is progress for all. ${ }^{153,}$

Women should therefore endeavour to obtain what it takes to avoid getting to the corridor of power through the back door, though evidence revealed that scores of women in Nigeria are well educated now and are capable of holding political offices like their male counterparts. They should therefore take their place of pride in politics as they have done in other fields of endeavour such as Law, Medicine, Engineering and other professions. They are advised to learn to fight a common cause. The paper also persuades women to make themselves readily available for participation in politics. "The equitable participation of women in decision making at all levels is the best approach to women empowerment. This is not only a demand for simple justice and democracy, but can be used as a necessary condition for women's".

Also, this paper charges the government to implement the protective legislations and soften the ground for parents to enable them give sound education to their female children and wards. Finally, considering the paradigm shift in the global political economy, efforts should be intensified by government

\footnotetext{
${ }^{151}$ Okoye (1993) at 20-21.

152 Ibid.

${ }^{153}$ Kermal (2006) at 65
} 
to sensitise women to be actively involved in politics and decision making. Concrete measure in this direction must be taken by the government to ensure women political participation in Nigeria.

\section{References}

Agbaegbu, T. (2000) 'Nigerian women: The struggle since independence, the gains and the losses' in News Watch Magazine. October, 2

Akande, J. (1999). '31 years of Nigerian Womanhood' in J. Akande (ed), Miscellany at law and gender relations, Lagos: MIJ publishers.

Akpan, N.E. (2015). Men without women: an analysis of the 2015 General Election in Nigeria, Independent National Electoral Commission 2015.

Alagoa, E.J. (1992), 'Queen Kambasa of Bonny' in B. Awe (ed.) Nigeria Women in Historical perspectives. Lagos: Sankoro Publishers.

Arowolo, D. (2010) 'Women and Political Participation in Nigeria,' in European Journal of Social science, Vol.14 (4):581. http://www.academia.edu/7018305

Awe, B. (1992). 'Saviours of their societies', in Awe, B. (ed), Nigeria Women in Historical perspectives, Lagos: Sankoro Publishers.

Bozimo, G.O. (2000). 'Economic Participation, Power Sharing, Decision Making and Women Education: A Conceptual Analysis' in Journal of Women in Academics, Vol 1:1.

Ciroma, M. (2006) - The Guardian News Paper (March, 9).

Ezeilo, J. (2001). Women and children rights in Nigeria. Enugu: Women's Aid Collective.

Gberevbie, D.E. \& F.O. Oviasogie (2013). 'Women in governance and sustainable development in Nigeria, 1999-2012' in Journal of Economic and Sociology Vol. 6: 90 .

Idike, A.N. (2015). 'The Jonathan's Administration and Women Empowerment in Nigeria: The Scorecard and Challenges.' in International Journal of Business and Social Sciences, 160(5). http://www.politicsscope.com,

Imam, A. (1993). 'Women in Nigeria: Kaduna State branch Position Paper on Nigeria's Political Future' in K.S. Shetimah (ed), Women in Transition to Democracy in Nigerian Politics, 1993. Kano: El rafiu Prints.

Kermal, D. (2006) The Guardian Newspapers (March, 9).

Klenke, K. (2011). Women in Leadership Contextual Dynamics and Boundaries UK: Emerald.

Kolade, T. (2011). 'Achieving 35\% affirmative action for women in Nigeria' The Tide Newspaper March 4, 2011. http://www.thetidenewsonline.com

Kura, S.M. \& B.U.Yore (2013). 'Analysis of gender inequality and National Gender Policy in Nigeria' in International Journal of Scientific and Engineering Research, Vol 4;1. www.ijser.org/researchpaper

Ladan, M.T. (1999.) Introduction to international human rights and humanitarian laws Zaria: Ahmadu: Bello University.

Njoku, J.E. (1980). The world of the African woman. London: Scacecrow Press Inco.

Nnoli, O. (2000). Government and politics in Africa: A reader 2000, Zimbabwe: Harare, AAPS Books.

Nwakwo, O. (2011). 'Reviewing 50 years of women participation in Politics' in Wascerids, Vol 2(1): 1-24.

Ogbu, O. (1999). Human rights law and practice in Nigeria: An introduction/ Enugu: CIDJAP press. 
Ogwu, J. (1997) 'Women in Development: Options and Dilemmas in the Human Rights Equations.' In Kalu, A. \& Y. Osinbanjo, Y. (eds), Perspective on Human Rights, Lagos: Federal Ministry of Justice.

Okoye, F. (1993). 'Women, Law and Transition to Democracy' in Women in Transition to Democracy in Nigerian Politics. Lagos: Sankoro Publishers.

Olateru-Olagbegi, B. \& B. Akiyode-Afolabi (2007). 'Actual Women Situation in Nigeria,' http://www/wildaf-ao.org/eng/articlephp37id-46

Ozo-Eson, P.I. (2000). 'Political Empowerment of Women: Prospects and Limitations' in Journal of Women in Academics (JOWACS), 111

Saad, A. (1992). 'Queen Amina of Zaria,' in B. Awe (ed.) Nigeria Women in Historical perspectives, Lagos: Sankoro Publishers.

Shettima, K.A. (1993) 'Constitutional Development, Party Politics and Prospects for Women' in Women in Transition to Democracy in Nigerian Politics, Lagos: Sankoro Publishers.

Sogbesan, H. (2015). 'Analysis of 2015 holds no promise for improved representation of women in politics,' at www.premiumtimesng.com.

Uchendu, P.K. (1995). Education and the Changing Role of Nigeria. Enugu: Fourth Dimension.

Yusuf, B. (1993) 'Women and the Transition Programme' in Women in Transition to Democracy in Nigerian Politics, Lagos: Sankoro Publishers. 
